\title{
Quoting the Canon, Demystifying Poetry: Bernardine Evaristo's The Emperor's Babe Between Tradition and Innovation
}

\author{
Maria Elena Capitani \\ University of Parma, Parma, Italy
}

\begin{abstract}
The award-winning British writer Bernardine Evaristo develops a creative approach to the politics of form and content in her verse-novel The Emperor's Babe, published in 2001 and set in Londinium in AD 211. This colourful reconstruction of Roman London is peopled with unforgettable characters, such as the teenage protagonist Zuleika, the daughter of Sudanese immigrants who becomes the wife of an absent man of status and the emperor's mistress. Believing that poetry should not be obscure and elitist, Evaristo opts for a highly intertextual and polyphonic novel in irregular verse which vividly rewrites the history of the black presence in Roman Britain from the perspective of the marginalized. In a unique way, in The Emperor's Babe, past and present, Romanitas and Britishness, tradition and the subversion of the canon intriguingly overlap, creating a multilayered narrative of resistance. In particular, this article focuses on Evaristo's radical poetics, demonstrating how this author creates a seemingly inaccessible and hybrid language which can be easily intelligible and appealing.
\end{abstract}

Keywords: Bernardine Evaristo, hybridization, verse fiction, canon, language

\section{Introduction}

Twenty-first century British literature is witnessing a fertile intermingling of tradition and experimentation, which is not exempt from (authorial) ambiguities: While claiming innovation, some contemporary writers seem to play safe by adhering to the "reassuring" literary canon. By contrast, Bernardine Evaristo adopts an unconventional approach to the politics of form and content in her verse novel The Emperor's Babe, first published in 2001 by Hamish Hamilton, which questions and dismembers well-established narrative structures, placing itself critically in relation to the Western canon.

Evaristo was born in 1959 in London to a black Nigerian father and a white English mother. Things complicate further: Her paternal grandfather was a Yoruba who returned from Brazil to Nigeria, the country of her paternal grandmother. Her mother's paternal great-grandfather arrived in London from Germany in the 1860s and settled in Woolwich, while her mother's maternal grandmother arrived in England from Ireland in the 1880s and stationed herself permanenly in Islington. As Sofía Muñoz Valdivieso (2004) wrote, Evaristo's

Maria Elena Capitani, Ph.D. (Doctor Europaeus), adjunct professor of English Literature and Language, Department of Humanities, Social Sciences, and Cultural Industries, University of Parma, Italy. 
Mixed background is usually seen as a source of strength in her writing. Hybridisation marks her work: She spins tales of a multiethnic world in a hybrid genre that moves skilfully between novel and verse, and her novels remain grounded in the present as they take us back in history. (Muñoz Valdivieso, 2004, p. 9)

Evaristo was educated at the Rose Bruford College of Speech and Drama and at Goldsmiths College, University of London, where she completed a Ph.D.. She is currently professor of Creative Writing at Brunel University, London. As an eclectic author, Evaristo has written eight books of fiction and verse fiction, for which she has received many honours, awards, nominations, as well as several dramas and creative works and narratives for BBC (British Broadcasting Corporation) Radio 3 and 4, theatre productions, fiction, poetry, and essays. She also writes literary criticism for national newspapers, including The Guardian and The Independent, and has judged many literary awards. In 2004, Evaristo was elected to become a Fellow of the Royal Society of Literature; in 2006, she was appointed a Fellow of the Royal Society of Literature; and in 2009, she was made an MBE (Member of the Order of the British Empire) in the Queen's Birthday Honours List for being "a major voice in the multicultural panorama of multicultural British literature" (Brunel University website). ${ }^{1}$

As Pilar Cuder-Domínguez (2004) argued, "London as a complex blend of cultures and ethnicities is very much at the heart of Evaristo's first two novels” (p. 176), Lara and The Emperor's Babe. Lara, first published in 1997, is largely autobiographical. It revolves around a mixed-race girl growing up in 1970s Britain and traces her family history across three continents and two centuries, from Brazil to London. Like Evaristo herself, Lara is the daughter of a white English mother and a black Nigerian father, growing up in the 1960s and 1970s in an intolerant society condemning her for her difference. The hybrid aspect is even more complex and multilayered: Her mother's family has nineteenth-century roots in both Ireland and Germany and her marriage to a black man puts at risk the upward mobility the family has so long striven for. Lara's father's heritage is also multiple: Taiwo da Costa descends from freed Yoruba slaves in Brazil who relocated to South Africa. He is raised in the best of English culture and studies at the Imperial College in London. In a sense, he is more English than the English. Lara's quest takes her on a long journey to her father's (and her own) roots: Only when she accepts her African origins does she become truly English.

\section{Rewriting History}

Evaristo's The Emperor's Babe, which was adapted into a BBC Radio 4 play in 2013, "takes her further in her project to inscribe the historical black presence in London" (Cuder-Domínguez, 2004, p. 178). She conceived the idea for her second novel in 1999, when she was writer in residence at the Museum of London, an institution which documents the history of the city from its first settlers to modern times. Besides, she was influenced by Peter Fryer's seminal study Staying Power: The History of Black People in Britain (1984). As Muñoz Valdivieso observed, The Emperor's Babe:

Seems to be an imaginative articulation of the opening sentence in Fryer's book: "There were Africans in Britain before the English came here", and she goes beyond any history book or archaeological find to create an irreverent tale of Roman London that merges past and present, history and fantasy, novel and verse. (Muñoz Valdivieso, 2004, p. 9)

\footnotetext{
1 Evaristo's personal page, Brunel University website (available at http://www.brunel.ac.uk/people/bernardine-evaristo, last accessed 20 December 2017).
} 
Aptly, Evaristo decides to open her book with an epigraph by Oscar Wilde: "The one duty we owe to history is to rewrite it" ( $p$. vii), which is entirely in keeping with her revisionist and, at the same time, re-visionary approach.

Initially, Evaristo wanted to write some poems about London's black history. Fascinated by the fact that black people lived in the metropolis during the Roman era, she developed the character of Zuleika and wrote a poem imagining her life:

I wanted to write about the black presence in Roman Britain. I then created a character who is Zuleika, who was actually called Claudia to begin with, and she wasn't actually a character. The Epilogue in The Emperor's Babe was actually the beginning; that was the first poem I wrote about the character and it was longer. And it was really about me the writer inhabiting, slipping into the skin of a dead black woman in Roman London. And then, I thought, well, there is so much potential here to explore, so then I started to write more and the character started to come alive and then the character started to write herself. That's what happens: The voice begins to take on its own life and as a writer you're just hurrying up, hurrying to keep up with her. (Muñoz Valdivieso, 2004, p. 12)

The original poem eventually turned into a novel in verse set in AD 211, in Londinium, Britannia, an outpost of the Roman Empire. This colourful reconstruction of Roman London, a "materfutuo urban jungle" (Evaristo, 2002, p. 201), is peopled with unforgettable characters, first of all, the sassy protagonist Zuleika, a very young black girl of Sudanese descent. Married off to Lucius Aurelius Felix, a rich, "obesus" (p. 17) Roman executive "thrice my age and thrice my girth" (p. 4) who is always away from home, Zuleika has to face the boredom of her sumptuous villa and the consequences of this imperialist "negotium" (p. 17) forcing her, in turn, to question her ex-centric identity:

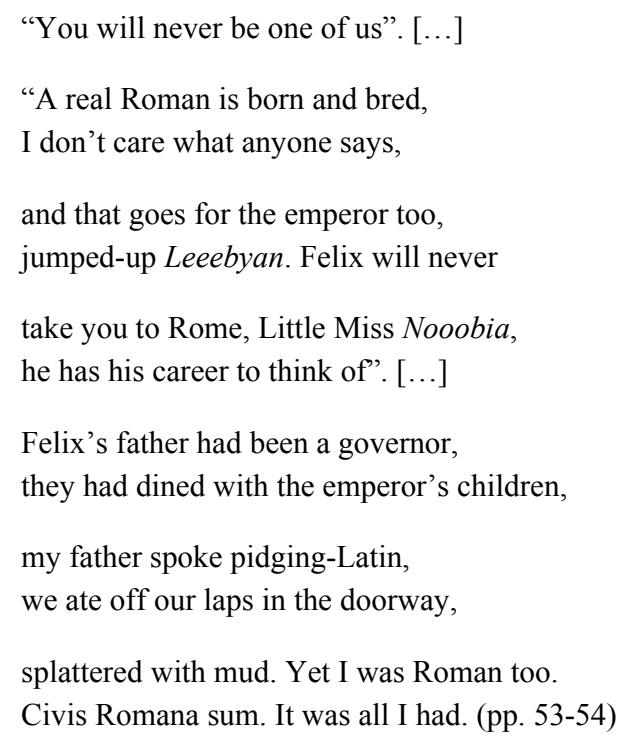

Zuleika has two Caledonian personal servants, Aemilia and Valeria, coming from the extreme periphery of the empire, and two close friends, Alba and Venus, a transvestite. As Cuder-Domínguez suggested, what Zuleika and her two friends share "is their inability to fit into traditional standards of 'Romanness' (a clever stand-in for “Englishness”). Here Evaristo's canvas has grown larger, as her exploration of Englishness features not only racial demands but also evokes an idealised heterosexual, educated, patriarchal middle-class" 
(Cuder-Domínguez, 2004, pp. 178-179). When Septimius Severus, a Libyan-born African Emperor, comes to town, Zuleika falls in love with him, without imagining the tragic consequences of this affair:

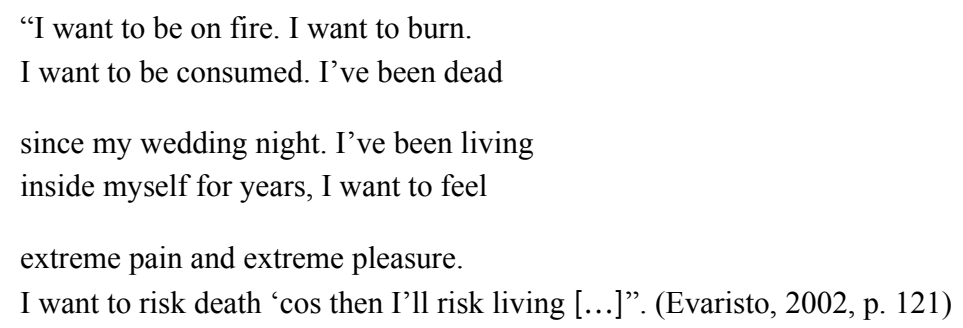

Evaristo opts for a highly intertextual and heteroglossic novel in irregular verse which vividly rewrites the widely-received "capital-H" History from the perspective of the marginalized, giving voice to the colonized and the dispossessed by telling their (personal) stories. In this light, Ester Gendusa (2015) observed, Evaristo's novel suggests that "the aim of the artistic imagination should not be so much to obliterate official history totally as to unseat its conventional presuppositions and re-write its arbitrary representations in non-exclusionary terms" (p. 49). In a unique way, in The Emperor's Babe, past and present, Romanitas and Britishness, tradition and the subversion of the canon intriguingly overlap, creating a multilayered narrative of resistance conveyed by a hybrid structure.

\section{Generic Hybridity and Poetic Accessibility}

The Emperor's Babe, as Katharine Burkitt argued, is one of those postcolonial works written at the turn of the twenty-first century revelling in generic cross-pollination. This formal hybridity:

Supports the notion of a post-epic text, because it is self-conscious in its engagement with the modern novel, as well as the older tradition of narrative poetry, epitomized in epic. It is therefore an exploration of the limitations of form and a harking-back to its literary genealogy. (Burkitt, 2007, p. 159)

As liminal literary artefacts, verse novels, such as Evaristo's Lara and The Emperor's Babe, Dorothy Porter's The Monkey's Mask (1994), Les Murray's Fredy Neptune (1998), Anne Carson's Autobiography of Red (1998), and Fred D'Aguiar's Bloodlines (2000), to name just a few, can be considered "post-epic" in that they adopt and adapt the traditional epic form while simultaneously express doubts about its value and function today. Remarkably, Burkitt (2007) suggested that these post-epic verse novels create a meta-literary zone which "is aware of their contentious engagement with postmodernism and post-colonialism, and are paradoxical and self-reflexive, as they highlight their own ambivalences and contradictions in order to critique the purported objectivity of epic history and mythology" (p. 159).

Engaging with the epic template by appropriating, rewriting, questioning, and undermining it from within and simultaneously re-(en)visioning it from an ex-centric point of view, Evaristo's polyphonic novel in verse aims to demystify the Graeco-Roman classics and Western literary canon at large, making poetry accessible to a wider public. As Evaristo herself declared in an interview, the poetic form is frequently defined as complex, obscure, and elitist. However, through her very personal hybridazation of two different genres, she is able to compose a kind of poetry which is quite easy to approach: 
I think there is a barrier to a lot of people reading it, because the idea of a whole novel told through poetry is for most people, you know, completely horrifying. That's because of how the poetry is taught in schools: People think that it will be dense and obscure and they won't be able to understand. In actual fact, both books I think are pretty easy, especially The Emperor's Babe. (Muñoz Valdivieso, 2004, p. 10)

\title{
Linguistic Cross-Pollination
}

The accessibility of Evaristo's writing should not lead us to diminish its fascinating linguistic cross-pollination and (inter)textual stratification, as the writer herself pointed out:

I've read a few novels-in-verse and they are all so different in terms of form that it's hard to generalise. Some are accessible, others so clogged up and dull that they give the form a bad name. [...] The thing to remember is that accessible writing need not be simplistic or any less sophisticated than more obscure, denser work. While my books are accessible on one level, they are also complex and layered; there are depths, references and allusions to plummet. (McCarthy, 2003)

Evaristo's multilayered, contemporary, and urban poetry is well exemplified by the following passage featuring an exchange between the teenage protagonist and her transgender friend Venus:

\author{
She turned back to me \\ "Let me ball-of-chalk you home, darlin". \\ You're a woman of means now. \\ Ain't no scamp no more. \\ Prime target for muggers and ne'er-do-wells. \\ "Yeah, right", I replied. What does Juvenal say? \\ Never go out to supper without \\ having first made your will." \\ "My dee-yah! You'll be quoting Plato next!" \\ “Actually, I've been studying poetry \\ with my professor, Theodorous. \\ I'm going to become a great poet. \\ I'd love to be famous for something. \\ Felix wants me educated, so how can he object?" (pp. 44-45).
}

In this passage, Evaristo “juxtaposes Venus's quasi-cockney-rhyming-slang with Zuleika's philosophical response", thus showing how The Emperor's Babe blends "linguistic play with philosophical debate as it marries novelistic narrative drive with a 'complex and layered' linguistic density which provides the [above-mentioned] 'depths, references and allusions to plummet'" (Burkitt, 2012, p. 29). It also emerges that Zuleika is a woman of driving ambition ("I want exposure / I want recognition. // I want a standing ovation!", p. 191), who struggles to express her creativity through writing and to counter the dominating patriarchal culture. The canon-related and oppressive male perspective is embodied by Theodorous, the authoritative teacher hired by Felix to educate his exotic child-bride. Trying to colonise her mind, the literature professor imposes the study of the classics on the aspiring poet, who finds the texts on the syllabus - from which female voices, with the exception of the Greek poet Sappho, are excluded - extremely boring, inappropriate, and out of fashion. In the following passage, which 
is worth quoting at length, Evaristo openly satirises the imperialist role played by the literary canon and especially by the epic genre, epitomized by Virgil's Aeneid:

\author{
He made me read Homer's Iliad, \\ which I found bloody tedious, quite frankly. \\ All about the siege of Troy. I mean, who cares? \\ Just an intsy-wintsy bit old-fashioned? \\ Theodorous says I shouldn't write poetry \\ until I've studied the last thousand years \\ of the canon, learnt it off by heart \\ and can quote from it at random, and imitate it \\ before attempting my own stuff, [...] \\ Then he made me learn Virgil's Aeneid \\ off by heart for my Roman History class. \\ It's all about the founding of Rome. And it's, \\ oh, only twelve books long. Contemporary \\ 'cos it's oh, only over two hundred years old. \\ You should hear him go on about Virgil, \\ noster maximus poeta, about how \\ the Aeneid will still be a classic text \\ in two millennia from now. As if. \\ Says all the notable poets were men, except \\ for some butch dyke who lived with a bunch \\ of lipstick lesbias on an island in Greece, \\ but she was really a minor poet [...]. (pp. 83-85)
}

\title{
Burkitt suggested that:
}

The tradition of epic ideology, as read by Theodorus [sic] [...], rather than just the form itself, is revealed as constraining and predetermined. Evaristo self-reflexively utilizes, yet critiques, an epic structure in order to vocalize a political agenda of race, gender, and literary hierarchy. (Burkitt, 2007, pp. 167-168)

Through Zuleika's rebellious voice, Evaristo voices the unvoiced subaltern position, oppressed and maintained by the hegemonic drive of the canon. Here, literature and literary studies are described, in Cuder-Domínguez's words, as “tools of the upper class in order to preserve their mores and the overall status-quo. Literature seems to be impervious to change and innovation, and as utterly deaf to Zuleika's own concerns and will to write" (p. 181). Indeed, rather than dealing with "war, death, the gods and the founding of countries", what "a thoroughly modern miss" such as Zuleika would like "to read/and hear is stuff about us, about now, /about Nubians in Londinium" (Evaristo, 2002, p. 85). 


\section{Conclusion}

In conclusion, creating a seemingly inaccessible and hybrid language- - "peppered with Latin, Italian, Cockney-rhyming slang, patois, American slang, pidgin Scots-Latin, and [...] broken English” (McCarthy, 2003) and interspersed with literary quotations-Bernardine Evaristo demythologises poetry demonstrating how it can be easily intelligible and appealing to a large readership. Blurring boundaries between "high" and "low" literature by dis-membering and re-membering the Western canon and juxtaposing classical referents with contemporary references, The Emperor's Babe thus offers a distinctive and subversive poetic texture which conveys the polyphony and stratification of a postmodern re-vision of antiquity filtered through a postcolonial lens.

\section{References}

Burkitt, K. (2007). Imperial reflections: The post-colonial verse-novel as post-epic. In L. Hardwick and C. Gillespie (Eds.), Classics in post-colonial worlds (pp. 157-169). Oxford: Oxford University Press.

Burkitt, K. (2012). Literary form as postcolonial critique: Epic proportions. Farnham and Burlington: Ashgate.

Cuder-Domínguez, P. (2004). Ethnic cartographies of London in Bernardine Evaristo and Zadie Smith. European Journal of English Studies, 8, 173-188.

Evaristo, B. (2002). The emperor's babe: A novel. London: Penguin.

Gendusa, E. (2015). Bernardine Evaristo's The Emperor's Babe: Re-narrating Roman Britannia, de-essentialising European history. Synthesis, 8, 47-62.

McCarthy, K. (2003). Bernardine Evaristo interviewed by Karen McCarthy. Valparaiso poetry review: Contemporary poetry and poetics, 4. Retrieved 10 October, 2017 from http://www.valpo.edu/vpr/evaristointerview.html

Muñoz Valdivieso, S. (2004). Interview with Bernardine Evaristo. Obsidian III: Literature in the African Diaspora, 5, 9-20. 